\title{
Perception towards Accounting Profession and Parental Influence to Predict Students Career Choices
}

\author{
Badingatus Solikhah, Trisni Suryarini, Samsul Bahri \\ Accounting Department \\ Universitas Negeri Semarang \\ Semarang, Indonesia \\ badingatusbety@mail.unnes.ac.id, trisnisuryarini@mail.unnes.ac.id, bahrisamsul09@gmail.com
}

\begin{abstract}
This study aims to obtain empirical evidence on the influence of student perceptions about accountant profession and parental influence toward students' career choices to become a public accountant. Based on Theory of Reason Action, this study also examines the effect of both independent variables on career choices behavior through intentions as an intervening variable. The population of this study is undergraduate accounting students and accounting profession institute students all over Semarang City. The respondents are students of 6th semester and above from 10 universities. The total size of incidental samples is 300 students. The data was analyzed using descriptive statistical analysis, path analysis, and Sobel test. The paper finds that the majority accounting students are interested in becoming a public accountant after they complete the study. Based on these results it can be concluded that partially, students perceptions of public accountant profession have a positive effect on intention, parental influence is not the consideration for the student's behavior intention. The results of this study indicate that behavioral intention can mediate the influence of student perceptions toward students career choices as a public accountant, but behavioral intention cannot mediate the effect of parental influence on student's behavioral to choose their career.
\end{abstract}

Keywords-indonesian public accountant; intentions; parental influence; students career choices; theory of reason action

\section{INTRODUCTION}

The curricula of Accounting Departments in Indonesia tend to lead the student to work as an accountant. After finishing the study, accounting students can choose some careers that can be lived, such as certified public accountant (CPA), corporate accountants, government accountants, internal auditors and junior researcher. CPA is a service profession primarily audit and the results of his work are widely used by the public as one of the important considerations in decision making [1]. Public accountants are required to reduce information asymmetry between principals (owners/investors) and agents (professional managers). Agents have more information than principal or creditor, consequently, the agent can make a decision to benefit himself, this can harm the interests of investors and not in accordance with the wishes of the principal [2].

In Indonesia, accounting study program is the favorite program in every new admission on campus. But the fact, the rising in a number of Indonesian students is not followed by increasing the number of CPA significantly. Until the beginning of 2018, the number of public accountants who obtained the practice license from the Indonesian Institute of Certified Public Accountants is 1334. The amount is still less when compared with the level of public accountant's needs in the market.

There are three aspects of career development that play a role in the choice of career, the first is self-efficacy, outcome expectations second, and the third is a personal goal. The career self-efficacy is the confidence and respect of individuals in taking action relating to the selection and adjustment of a choice [3]. Found that students who have work experience and major in non-accounting disciplines were discouraged to become a CPA [4]. On the other hand, the research conducted by Merdekawati and Sulistyawati identified the factors influence to entering the accounting profession without using the theoretical framework [5]. In order to investigate how best to attract students to the accounting profession, this study uses the theory of reasoned action (TRA) developed by Ajzen [6].

Used TRA model in his study and found that two constructs in the model - "intrinsic factors" (attitude toward the behavior) and "parental influence" (subjective norm), make significant and independent contributions to predicting the career choice of accounting students [7].

This study aims to determine the factors that can influence career selection to become a public accountant by using the model of the planned behavior theory.

\section{THEORETICAL}

\section{A. Theory of Reasoned Action (TRA)}

Theory of Reasoned Action (TRA) was developed using the cognitive approach, the basic idea that: "... humans are reasonable animals who deciding what actions to take, systematically process and utilized the information available to them" [8]. The TRA model explains its origins in the arena of social psychology science figure 1 . This model developed by Fishbein and Ajzen in 1980 states the links between some psychological variables: beliefs, attitudes, norms, intentions, and behaviors of individuals. Allowing to this model, a human's behavior is determined by its behavioral intention to perform this theory. Ajzen give opinion that this intention is itself determined by the person's attitudes and their subjective 
norms towards the behavior [7]. Fishbein and Ajzen designate the subjective norms as "the person's perception that most people who are important to him think he should or should not perform the behavior in question" [8].

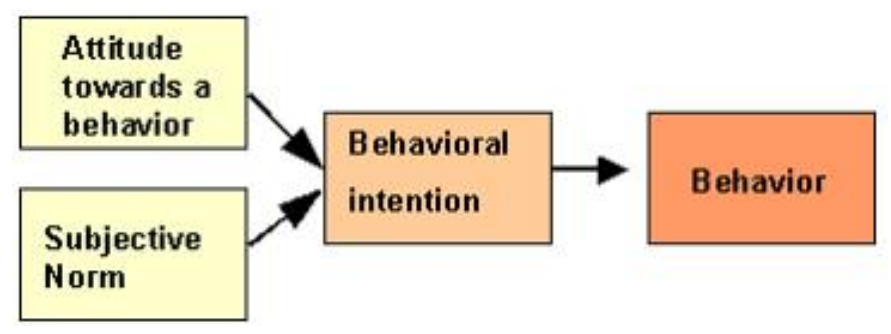

Fig. 1. Theory of reasoned action.

The advantage of using TRA compared with other behavioral theory is that this theory can analyze the behavior of the components in the operational items [8]. In this case, the individual behavior is defined as the act or real activities conducted by an individual and is very closely related to the interests of individual behavior (behavioral intention).

\section{B. Hypotheses Development}

1) The relationship of students perception and intention to become CPA :Prior studies have indicated that the attitudes towards accounting are determined by a number of different factors [4], [9], [7], [10] avily influenced by their perceptions of accounting [11], [12], [13]. The stereotypical negative perception of the public accountants has concerned researchers as these perceptions can deter students from studying accounting and pursuing a career in accounting profession [14]. However, other studies argue that even public accountants may be observed as having a negative image, students may consider the job satisfaction, salary when they choose to study in accounting. Fourthemore, Jackling found that students have a positive perception towards accounting as a profession [10]. Positive perceptions about the accounting profession will encourage accounting students to choose a career as a public accountant. The hypothesis is stated as follow:

$\mathrm{Ha}^{1}$ : A positive perceptions toward accounting profession will be a positive influence on behavioral intention to become public accountant.

$\mathrm{Ha}^{2}$ : A positive perceptions toward accountant profession will produce stronger intentions lead to increased effort to become a public accountant.

2) The relationship of parental influence and intention to become CPA : Ajzen and Fishbein propose that subjective norm is one of the mechanisms in the Theory of Reason Action. According to this model, a person's behavior is determined by his behavioral intent to do so. Therefore, the overall subjective norm can be expressed as the number of individual perceptions $\mathrm{x}$ motivation ratings for all relevant references. Confidence is defined by a person's subjective probability that performing a particular behavior will produce a specific outcome. This model, therefore, shows that external stimuli affect attitudes by modifying the person's trust structure. In addition, behavioral intentions are also determined by subjective norms determined by the normative belief of an individual and by his motivation to comply with norms [8]. Jackling and Keneley using a cohort of Australian and international students, the paper prove that there was a greater likelihood that international students will be influenced in their choice to major in accounting by "reference groups" than Australian students [9]. The contribution of the opinion of each particular referent is weighted by the motivation that a person must obey the wishes of the referent. External impulses such as parental and family influence, spousal support, and teachers encourage will influence the intention to pursue a CPA career. Therefore, the hypothesis can be formulated as:

$\mathrm{Ha}^{3}$ : Parental influence will affect positively toward intention to become public accountant

$\mathrm{Ha}^{4}$ : Parental influence will affect positively toward students intention lead to increased effort to become a public accountant

\section{METHOD}

This paper uses a quantitative research design that aims to test the hypothesis. The respondents involved in this study are accounting students of 6th semester and above from 9 universities and 1 accounting profession school in Semarang, Central Java, Indonesia. The number of respondents was collected through incidental sampling technique. The instrument for the research was a questionnaire survey of last year accounting students. The study focused on last year accounting students because they have already studied all subjects about accounting. If so, they have made their career decisions and mostly they have had internship experience in the company. Respondents should answer all open form questions using a Likert scale from 1 ("strongly disagree") to 5 ("strongly agree"). Before being used as to take the data, the questionnaire must be tested both reliability and validity. A total of 300 students completed both of online and offline survey. The next step was to analyze the data, the method of analysis used in this study was: (1) descriptive analysis, (2) inferential analysis using ordinary least square and Sobel test. Data analysis used in this research is multiple regression analysis using SPSS version 21.

\section{RESULTS AND DISCUSSION}

\section{A. Descriptive Statistics}

Table I describe the statistic value consisting of minimum, maximum, mean and standart deviation of variables. $62.67 \%$ respondents intend to choose CPA as a career after they have graduated from college or graduated from professional school. Students have positive perceptions toward accounting profession especially "Certified Public Accountant" (CPA). They believe that CPA could provide a favorable expectation for the future of both salary, career development, and reputation. This finding alike with the previous study by [10]. 
TABLE I. Descreptif Statitic Test

\begin{tabular}{|c|c|c|c|c|c|}
\hline Variable & $\mathbf{n}$ & Min & Max & Mean & Std. Deviation \\
\hline PERCEPT & 300 & 7.00 & 35.00 & 4.12 & 3.33 \\
\hline PARENT & 300 & 4.00 & 20.00 & 3.27 & 3.25 \\
\hline INTENT & 300 & 3.00 & 15.00 & 3.87 & 1.71 \\
\hline CAREER & 300 & \multicolumn{2}{|l}{$\begin{array}{l}\text { Want to become CPA } \\
\text { Do not want to become CPA 112 (37.,33\%) }\end{array}$} \\
\hline
\end{tabular}

b. NOTE: PERCEPT = students perception toward accountant, PARENT = parental influence, INTENT $=$ students intentions toward accountant, CAREER $=$ students career choice to become CPA

\section{B. Regression Test and Sobel Test}

TABLE II. REgRESSION TEST AND Sobel TeSt RESUlt

\begin{tabular}{|c|c|c|c|c|c|}
\hline \multirow[t]{2}{*}{ Model } & \multicolumn{2}{|c|}{$\begin{array}{c}\text { Unstandardiz } \\
\text { ed } \\
\text { Coefficients }\end{array}$} & \multirow{2}{*}{$\begin{array}{c}\begin{array}{c}\text { Standard } \\
\text { ized } \\
\text { Coefficie } \\
\text { nts }\end{array} \\
\text { Beta }\end{array}$} & \multirow[t]{2}{*}{$\mathbf{T}$} & \multirow[t]{2}{*}{ Sig. } \\
\hline & $B$ & $\begin{array}{c}\text { Std. } \\
\text { Error }\end{array}$ & & & \\
\hline (Constant) & 3.727 & 0.804 & & 4.633 & 0.000 \\
\hline PERCEPT $\rightarrow$ INTENT & 0.209 & 0.028 & 0.401 & 7.474 & $0.000^{* * *}$ \\
\hline PARENT $\rightarrow$ INTENT & 0.036 & 0.028 & 0.066 & 1.269 & 0.206 \\
\hline $\begin{array}{l}\text { PERCEPT } \rightarrow \text { INTENT } \rightarrow \\
\text { CAREER }\end{array}$ & \multicolumn{5}{|c|}{$\begin{array}{l}\text { Standardized Coefficients }=0.057 \\
\mathrm{Z}=4.890^{* * *}>\mathrm{Z}_{\mathrm{tab}(5 \%)} 1.96\end{array}$} \\
\hline $\begin{array}{l}\text { PARENT } \rightarrow \text { INTENT } \rightarrow \\
\text { CAREER }\end{array}$ & \multicolumn{5}{|c|}{$\begin{array}{l}\text { Standardized Coefficients }=-0.012 \\
\mathrm{Z}=1.247<\mathrm{Z}_{\mathrm{tab}(5 \%)} 1.96\end{array}$} \\
\hline
\end{tabular}

\section{Students Perceptions toward CPA and Their Career Selection Behavior}

Perceptions of the profession of public accountants are influenced by the image attached to the profession, the response is an integral part of the community environment [15]. People generally recognize a profession depending on the business being undertaken and what services the profession provides to the community according to the skills they have [16].

Positive perceptions and attitudes toward the Certified Public Accountant (CPA) profession have a positive and significant impact on their intention to choose their career as CPAs [4]; [7]. The Theory Reason Action (TRA) asserts that the intention to perform or not to do certain behaviors is influenced by two basic determinants, the first is attituderelated behavior and subjective norm [8].

Pursuant to result of path analysis and Sobel test, it is indicated that student perception toward accountant will increase their behavior intention lead to students behavior to prepare future career to become a public accountant. This finding supports prior studies [17], [7], [4], [10].

\section{Parental Influence and Their Career Selection Behavior}

Subjective norm can influence someone to choose CPA career. In this paper, parental influence is proxy for the subjective norm. TRA model suggests the stronger subjective norm should increase the person's intention to pursue CPA career. Based on the results of the study (direct effect and no direct effect) showed that parental influence has no significant effect on career intentions directly. This is a surprising finding because as opposed to TRA Model and some previous study.

This research differs from the opinion of which provides the positive and significant influence of subjective norms as external views and encouragement (eg from parents, family, teachers, and friends) to the interests of students who want to become public accountants [13]. In addition, this result is contrary to Ahmadi who examined the effects of various job selection factors on accountants, the paper found that the subjective norm (mentioned in this study as external influences) strongly influenced the male accountant in choosing a job [18].

The insignificance of the third and fourth hypothesis because in this study only focus on external factor from the parents. Most of the respondents' parents in this study do not work in the accounting profession. Besides the encouragement and advice from parents, the more dominant influence of career selection behavior to be a public accountant is the advice of lecturers. Also pointed out that the greatest influence for them is derived from the university professors where they were in college [18].

\section{CONCLUSION}

The purpose of this study is to explore students' behavior to choose their career as Certified Public Accountants based on Theory of Reason Action Model. The result partially confirms TRA model, a positive perception toward a profession produce stronger behavioral intentions and lead to increased students interest to become a public accountant. Based on the results of the study showed that parental influence has no significant effect on career intentions.

\section{REFERENCES}

[1] A.A. Arens, R.J. Elder, and M.S. Beasly, "Auditing and Assurance Services: An Integrated Approach," Pearson Prentice Hall International Inc. New Jersey, 2013.

[2] M. Jensen, and W. Meckling, "Theory of the Firm: Managerial Behavior Agency Cost, and Ownership Structure," Journal of Finance Economics 3, vol. 11, No. 5, pp. 305-360, 1976.

[3] R.W. Lent, S.D. Brown, and G. Hackett, Career Development From A Social Cognitive Perspective, In D. Brown, L. Brooks, \& Associates, Career Choice and Development, $3^{\text {rd }}$ ed, San Francisco : Sossey-Bass, 1996.

[4] S. Sugahara, K. Hiramatsu, and G. Boland, The Accounting Profession as a Career Choice for Tertiary Business Students in Japan- a Factor Analysis, Accounting Education, vol. 18, No. 3, pp. 255 - 272, 2009.

[5] D.P. Merdekawati, and A.I. Sulistyawati, "Factors Affecting Career Options as Public Accountants and Non Public Accountants," Jurnal Ilmu Ekonomi ASET, vol. 13, No.1, pp. 9-19, 2011.

[6] I. Ajzen, Attitudes, Personality, and Behavior, Milton Keynes : Open University Press, 1988.

[7] K.L. Philip, A Theory of Reasoned Action Model of Accounting Students' Career Choice in Public Accounting Practices in the PostEnron, Journal of Applied Accounting Research, vol. 11, No. 1, pp. 5873, 2010. ZSa 
[8] I. Ajzen, and M. Fishbein, Understanding attitudes and predicting social behavior, New Jersey : Prentice-Hall International Inc, 1980.

[9] B. Jackling, and M. Keneley, "Influences on the supply of accounting graduates in Australia: a focus on international students, Accounting and Finance, vol. 49, pp. 141-59, 2009.

[10] B. Jackling, P. Lange, J. Phillips, and J. Sewell, "Attitudes towards accounting: differences between Australian and international students," Accounting Research Journal, vol. 25, No. 2, pp. 113-130, 2012.

[11] S.J. Adams, L.J. Pryor, and S.L. Adams, "Attraction and retention of high-aptitude students in accounting: an exploratory longitudinal study, Issues in Accounting Education, vol. 9, No. 1, pp. 45-58, 1994.

[12] S. Mauldin, J.L. Crain, and P.H. Mounce, "The accounting principles instructor's influence on students' decision to major in accounting, Journal of Education for Business, vol. 75, No. 3, pp. 142-8, 2000.

[13] S. Ikhsan, B. Solikhah, and N. Susilowati, "The Impact of Implementation of Public Accountant Act on Students' Intention Becoming a Public Accountant Case Study of Accounting Students of Semarang State University," Jurnal Dinamika Akuntansi, vol. 5, No.2, pp. 99-108, 2013.
[14] R. Mladenovic, "An investigation into ways of challenging introductory accounting students' negative perceptions of accounting, Accounting Education, vol. 9, No. 2, pp. 135-55, 2000.

[15] N. Alimah, and L. Agustina, "Faktor-Faktor Yang Mempengaruhi Minat Mahasiswa Mengikuti Pendidikan Profesi Akuntan (PPA), Accounting Analysis Journal, vol 3, No.1, pp. 118-125, 2014.

[16] L. Harris, and A. Djamhuri, "Analysis of Underlying Factors Careers Selection For Accounting Students: Between Public Accountant Versus Non Public Accountant," Jurnal Penelitian, vol. 2, No. 2, pp. 116-135, 2001 .

[17] B. Jackling, and C. Calero, Influences on undergraduate students' intentions to become qualified accountants: evidence from Australia, Accounting Education: An International Journal, vol. 15, No. 4, pp. 41938, 2006.

[18] M. Ahmadi, M. Marilyn, Helms, and N. Patricia, "A Factor-Analytic Approach Profiling Job Selection Differences of Male and Female Accountants," Managerial Auditing Journal, vol. 10, No. 7, pp. 17-24, 1995. 